\title{
$\mathrm{COSci}_{\text {ech }}$ Jurnal Computer Science and Information Technology (CoSciTech)
}

\section{Analisis Perbandingan Performa Codec H.264 \& H.265 Video Streaming Dari Segi Quality of Service}

Indra Saputra ${ }^{1}$, Harun Mukhtar ${ }^{2 *}$, Januar Al Amien ${ }^{3}$

Email: ${ }^{1}$ saputraindra@gmail.com, ${ }^{2}$ harunmukhtar@umri.ac.id, ${ }^{3}$ januaralamien@umri.ac.id

${ }^{1}$ Teknik Informatika, Fakultas Ilmu Komputer, Universitas Muhammadiyah Riau

${ }^{2}$ Teknik Informatika, Fakultas Ilmu Komputer, Universitas Muhammadiyah Riau

${ }^{3}$ Teknik Informatika, Fakultas Ilmu Komputer, Universitas Muhammadiyah Riau

\begin{abstract}
Abstrak
Video streaming merupakan teknologi yang sering digunakan ketika menonton video di internet tanpa harus mengunduh video tersebut untuk memutarnya. Beberapa permasalahan yang mempengaruhi performansi dari video streaming yaitu seperti besarnya kapasitas ukuran video, kapasitas ukuran video mempengaruhi kelancaran saat melakukan streaming video. Pada penelitian ini akan dilakukan perbandingan dua metode kompresi video yaitu codec H.264 dan codec H.265. pengujian dilakukan untuk mengetahui efek dari penggunaan metode kompresi menurut perubahan codec dan framerate yang digunakan. Setelah melakukan pengujian kedua codec tersebut dapat ditarik kesimpulan bahwa codec H.265 lebih efektif untuk diterapkan dari pada codec H.264.
\end{abstract}

Kata kunci: video streaming, streaming store, quality of service, H.264, H.265

\section{Comparative Analysis of H.264 \& H.265 Video Streaming Codec Performance in terms of Quality of} Service

\begin{abstract}
Video streaming is a technology that is often used when watching videos on the internet without having to download then video to play it. Some problems that affect the performance of video streaming are such as the large capacity of the video size, the capacity of the video size affects the smoothness when streaming video. In this research, two video compression methods will be compared, namely H.264 codec and H.265 codec. The test is carried out to determine the effect of using the compression method according to changes in the codec ang framerate used. After testing the two codec, it can be concluded that the H.265 codec is more effective to apply than the H.264 codec.
\end{abstract}

Keywords: video streaming, streaming store, quality of service, H.264, H.265

\section{Pendahuluan}

Perkembangan akan pemakaian internet semakin meluas khususnya dalam bidang jaringan. Saat ini orang berkomunikasi tidak hanya dengan suara maupun teks, tetapi juga secara visual dengan menggunakan video, salah satu teknologi yang tren saat ini adalah teknologi video streaming. Video streaming adalah istilah yang sering digunakan saat melihat video di internet melalui browser dimana pengguna tidak perlu mengunduh file video-audio tersebut untuk dapat memutarnya.[1] Banyak website di internet yang menyediakan jasa streaming video seperti youtube bahkan media sosial memiliki fitur video streaming. Dengan adanya teknologi seperti video streaming mempermudah dalam mendapatkan informasi dalam bentuk tampilan video, semakin mudah mendapatkan akses internet maka semakin mudah juga untuk mendapatkan berbagai informasi dan juga dapat menikmati berbagai macam hiburan dalam bentuk tampilan video yang telah disediakan oleh website video streaming. 
Saat melakukan streaming video maka akan terbentuk sebuah buffer di komputer dan data video dan audio tersebut akan mulai di download kedalam kantong buffer yang telah terbentuk pada mesin komputer. Dalam waktu sepersekian detik kantong buffer akan mulai terisi dan secara otomatis file video dan audio akan dijalankan oleh sistem dan sistem akan membaca informasi dari buffer sambil tetap melakukan download file video dan audio kedalam kantong buffer sehingga proses streaming tetap berlangsung. Permasalahan yang terjadi adalah setiap video yang kemudian akan di streaming memiliki ukuran kapasitas video yang besar, kualitas jaringan mempengaruhi kelancaran saat melakukan streaming video karena setiap video streaming memiliki ukuran dan kualitas video yang berbeda apakah video yang diputar dalam resolusi tinggi atau resolusi rendah.

Video streaming dapat diartikan sebagai suatu metode yang memanfaatkan streaming server untuk mentransmisikan video digital melalui suatu jaringan data sehingga memungkinkan video playback dapat langsung dilakukan tanpa perlu menunggu sampai proses download selesai ataupun menyimpannya terlebih dahulu di komputer client. Sistem video streaming melibatkan proses encoding terhadap isi dari data video, dan kemudian mentransmisikan video stream melalui suatu jaringan, sehingga client dapat mengakses, melakukan decoding, dan memunculkan video tersebut secara real-time[2]. Sistem VoD memungkinkan pengguna untuk memilih dan menyaksikan video yang hendak diakses dalam jaringan sebagai bagian dari sistem interaktif. $\mathrm{VoD}$ dapat memanfaatkan proses streaming, progressive downloading, ataupun download. Sistem VoD juga memungkinkan pengguna untuk melakukan kendali, seperti pause, fast forward, fast rewind, slow forward, dan lain-lain.[3]. Kompresi video mengacu untuk mengurangi jumlah data yang digunakan untuk mewakili video digital gambar dan merupakan kombinasi dari ruang kompresi gambar dan temporal kompensasi gerak. Kompresi video adalah contoh dari konsep pengkodean sumber dalam teori informasi. Banyak teknik pengkodean kompresi video telah dikembangkan untuk mengurangi redudansi diantaranya adalah transform coding, entropi coding, dan loop filter[4]. Codec H.264 dapat melakukan proses decoding secara lengkap, inverse transform untuk menghasilkan sebuah urutan video yang telah di-encode. Standar H.264 menawarkan fleksibilitas yang lebih besar dari segi kompresi dan transmisi. Sebuah encoder H.264 dapat memilih dari berbagai jenis alat kompresi, sehingga cocok untuk aplikasi mulai dari bitrate rendah hingga transmisi HDTV ke konsumen televisi[5].

Tahun 2004, ITU-T Video Coding ahli Group (VCEG) memulai pengembangan penerus codec H.264 dan dalam 2007 ISO/IEC Moving Picture ahli Group (MPEG) mulai perjalanan mereka ke arah yang sama. H.265 atau High Efficiency Video Coding (HEVC) merupakan codec yang memiliki kualitas video yang setara dengan codec yang ada saat ini yaitu H.264 namun codec H.265 hanya membutuhkan setengah bandwith dari codec H.264[4]. PLEX adalah suatu media server yang digunakan untuk mendistribusikan konten multimedia kepada klien (Gerakan Open Source Wordpress). Salah satu kelebihan PLEX adalah adanya fitur transcoding. Dengan fitur ini maka kita tidak perlu memusingkan apakah perangkat kita bisa memutar konten multimedia yang ada di server karena saat kita memutar konten multimedia maka PLEX akan otomatis melakukan transcoding secara realtime[6]. Quality of Service merupakan metode pengukuran tentang seberapa baik jaringan dan merupakan suatu usaha untuk mendefenisikan karakteristik dan sifat dari satu servis. QoS digunakan untuk mengukur sekumpulan atribut kinerja yang telah dispesikasikan dan diasosiasikan dengan suatu servis[7]. Throughput yaitu kecepatan (rate) transfer data efektif, yang diukur dalam bps (bit per second). Throughput adalah jumlah kedatangan paket yang sukses yang diamati pada tujuan selama interval waktu tertentu dibagi oleh durasi interval waktu tersebut. Rumus yang digunakan untuk menghitung throughput adala[8] :

$$
\text { Throughput }=\frac{\text { total bytes }}{\text { duration }}
$$

Keterangan:

Bytes = jumlah bit yang dikirim

Duration $=$ total waktu pengiriman paket

Delay (Latency) merupakan waktu yang dibutuhkan data untuk menempuh jarak dari asal ke tujuan. Delay dapat dipengaruhi oleh jarak, media fisik, congesti atau juga waktu proses yang lama.[9] Rumus yang digunakan untuk menghitung delay adalah: Rata - Rata delay $=\frac{\text { jumlah delay }}{\text { banyak delay }}$

\section{Keterangan:}

Jumlah delay $\quad=$ total delay pengiriman paket

Banyak delay = banyaknya delay yang terjadi. Kategori delay dapat dilihat pada tabel 1.

Tabel 1 Kategori Delay

\begin{tabular}{|c|c|c|}
\hline Kategori Delay & Besar Delay (ms) & Indeks \\
\hline Sangat Bagus & $<150 \mathrm{~ms}$ & 4 \\
\hline Bagus & $150 \mathrm{~ms}-300 \mathrm{~ms}$ & 3 \\
\hline Sedang & $300 \mathrm{~ms}-450 \mathrm{~ms}$ & 2 \\
\hline Jelek & $>450 \mathrm{~ms}$ & 1 \\
\hline
\end{tabular}

Packet Loss merupakan suatu parameter yang menggambarkan suatu kondisi yang menunjukan jumlah total paket yang hilang dapat terjadi karena collision dan congestion pada jaringan. Rumus yang digunakan untuk menghitung packet loss adalah : 
Packet LosS $=\frac{\text { Paket kirim-Paket terima }}{\text { Paket Terkirim }} \times 100 \%$

Keterangan:

Paket terkirim = total RTP packet yang terkirim

Paket diterima = paket yang berhasil diterima

Kategori paket lost dapat dilihat pada tabel 2.

Tabel 2 Kategori Packet Loss

\begin{tabular}{|c|c|c|}
\hline Kategori Packet Loss & Packet Loss (\%) & Indeks \\
\hline Sangat Bagus & $0 \%$ & 4 \\
\hline Bagus & $3 \%$ & 3 \\
\hline Sedang & $15 \%$ & 2 \\
\hline Jelek & $25 \%$ & 1 \\
\hline
\end{tabular}

Wireshark adalah sebuah network packet analyzer akan mencoba menangkap paket-paket jaringan dan berusaha untuk menampilkan semua informasi dipaket tersebut se-detail mungkin. Dulunya tool-tool semacam ini sangatlah mahal harganya, dan biasanya dengan embel-embel hak cipta. Namun dengan adanya wireshark, kita akan sangat dimudahkan. Oleh karena itu tidak sedikit yang bilang bahwa wireshark adalah salah satu tool gratis (dan bukan open source) terbaik untuk menganalisa jaringan.[1]

\section{METODE PENELITIAN}

\section{1 kerangka Penelitian}

Kerangka penelitian ini terdiri dari 4 langkah yang dimulai dari pengumpulan data sampai ke pengujian sebagai mana terlihat pada 1 dibawah ini.

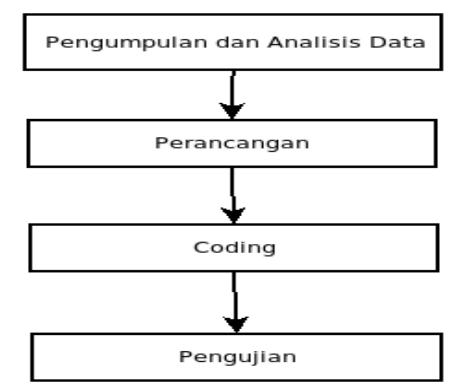

Gambar 1: Alur Penelitian

\subsection{Kebutuhan Perangkat Keras}

Tahap ini penulis melakukan analisa kebutuhan yaitu merupakan langkah awal dalam menentukan perangkat keras dan perangkat lunak yang baik dan sesuai dengan kebutuhan pada saat melakukan implementasi. Adapun perangkat keras dan perangkat lunak yang dibutuhkan sebagai berikut:
a. Komputer Server dan client.
b. RouterBoard 941 .
c. Kabel UTP dan RJ 45.
d. PLEX media server.
e. Wireshark.
f. Winbox.

\section{HASIL PEMBAHASAN}

Hasil dari penelitian ini berupa video streaming dimana program yang di tampilkan sudah terlebih dahulu direkam atau disimpan dalam server yang disebut video on demand, video tersebut telah dikompresi ke dalam codec H.264 dan codec H.265. Selanjutnya akan diuji quality of service berdasarkan parameter throughput, delay dan packet loss. 


\subsection{Hasil Analisa Pixel 1280 x 72030 fps dan 60 fps Codec H.264 dan H.265}

Terlihat pada tabel 4.5 dan gambar 4.20 video yang dikompresi menggunakan codec H.264 dengan frame rate 30 fps mendapatkan hasil throughput $0,12 \mathrm{Mbps}$, dan untuk delay mendapatkan hasil 8,33s, dan untuk packet loss mendapatkan hasil $1,86 \%$. Video yang dikompresi menggunakan codec H.265 dengan frame rate $30 \mathrm{fps}$ mendapatkan hasil throughput 0,36 Mbps, dan untuk delay mendapatkan hasil 2,76s, dan untuk packet loss mendapatkan hasil 1,17\%. Untuk video yang dikompresi menggunakan codec H.264 dengan frame rate 60 fps mendapatkan hasil throughput 0,12 Mbps, dan untuk delay mendapatkan hasil 8,2s, dan untuk packet loss mendapatkan hasil 1,74\%. Untuk video yang dikompresi menggunakan codec H.265 dengan frame rate $60 \mathrm{fps}$ mendapatkan hasil throughput $0,33 \mathrm{Mbps}$,dan untuk delay mendapatkan hasil 2,99s, dan untuk packet loss mendapatkan hasil 1,24\%. Dari hasil analisa quality of service video yang dikompresi menggunakan codec H.265 lebih efektif untuk diterapkan, karena mendapatkan hasil throughput yang besar, dengan hasil delay dan packet loss yang lebih rendah dibandingkan video yang dikompresi menggunakan codec H.264

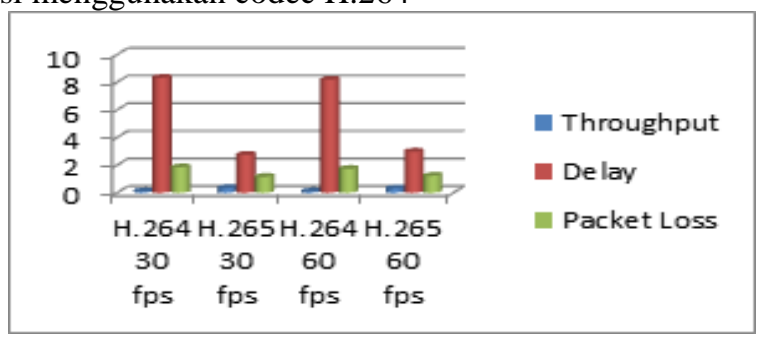

Gambar 2: Grafik Pixel 1280x720 30 fps dan 60 fps Codec H.264 dan H.265

\subsection{Hasil Analisa Pixel 1920 x 108030 fps dan 60 fps Codec H.264 dan H.265}

Terlihat pada tabel 4.6 dan gambar 4.21 video yang dikompresi menggunakan codec H.264 dengan frame rate 30 fps mendapatkan hasil throughput 0,22 Mbps, dan untuk delay mendapatkan hasil 4,23s, dan untuk packet loss mendapatkan hasil 0,96\%. Video yang dikompresi menggunakan codec H.265 dengan frame rate $30 \mathrm{fps}$ mendapatkan hasil throughput 0,46 Mbps, dan untuk delay mendapatkan hasil $2,14 \mathrm{~s}$, dan untuk packet loss mendapatkan hasil 0,84\%. Video yang dikompresi menggunakan codec H.264 dengan frame rate 60 fps mendapatkan hasil throughput 0,25 Mbps, dan untuk delay mendapatkan hasil 3,79s, dan untuk packet loss mendapatkan hasil 0,9\%. Video yang dikompresi menggunakan codec H.265 dengan frame rate $60 \mathrm{fps}$ mendapatkan hasil throughput 0,36 Mbps, dan untuk delay mendapatkan hasil 2,73s, dan untuk packet loss mendapatkan hasil 0,86\%. Dari hasil analisa quality of service video yang dikompresi menggunakan codec H.265 lebih efektif untuk diterapkan, karena mendapatkan hasil throughput yang besar, dengan hasil delay dan packet loss yang lebih rendah dibandingkan video yang dikompresi menggunakan codec H.264.

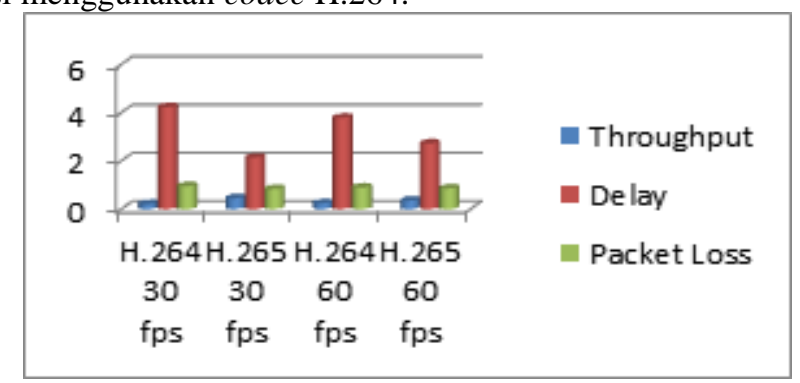

Gambar 3: Grafik Pixel 1920x1080 30 fps dan 60 fps Codec H.264 dan H.265

\subsection{Perbandingan Codec H.264 dan Codec H.265}

Hasil perbandingan codec H.264 dan Codec H.265 meliputi keseluruhan implementasi, dapat ditarik kesimpulan bahwa codec H.265 lebih efektif untuk diterapkan dari pada codec H.264, karena codec H.265 mempunyai bobot efektif yang lebih banyak dari pada codec H.264, dapat dilihat pada tabel 3.

Tabel 3 Perbandingan Codec H.254 dan Codec H.265

\begin{tabular}{|c|c|c|c|}
\hline No & Keterangan & $\begin{array}{c}\text { Codec } \\
\text { H.264 }\end{array}$ & $\begin{array}{c}\text { Codec } \\
\text { H.265 }\end{array}$ \\
\hline 1 & Throughput & Buruk & Baik \\
\hline 2 & Delay & Buruk & Baik \\
\hline 3 & Packet Loss & Buruk & Baik \\
\hline 4 & $\begin{array}{c}\text { Kapasitas } \\
\text { Penyimpanan }\end{array}$ & Buruk & Baik \\
\hline 5 & $\begin{array}{c}\text { Durasi } \\
\text { Kompresi }\end{array}$ & Baik & Buruk \\
\hline 6 & Fleksibelitas & Baik & Buruk \\
\hline
\end{tabular}




\section{KESIMPULAN}

Berdasarkan hasil pengujian dan analisis yang telah dilakukan, maka dapat diambil kesimpulan yaitu Codec H.264 dan codec H.265 bertujuan dalam memperkecil kapasitas ukuran video, masing-masing codec memiliki kelebihan dan kekurangan. Saat melakukan streaming video, codec H.264 terlebih dahulu menjalankan video streaming dari pada codec H.265, karena codec H.264 lebih fleksibel dalam pemilihan perangkat. Sedangkan untuk menjalankan video dengan codec H.265 membutuhkan spesifikasi perangkat yang lebih tinggi.

Dari segi parameter quality of service dapat ditarik kesimpulan bahwa codec H.265 lebih efektif dari codec H.264, karena codec H.265 mendapat nilai throughput, delay, dan packet loss yang lebih baik dari codec H.264.Kesimpulan berisi fakta yang didapatkan dari hasil penelitian. Dalam kesimpulan tidak boleh ada referensi.

\section{DAfTAR Pustaka}

[1] A. Sangsari, “Layanan Video Streaming Yang Messaging Protocol ),” vol. 2, no. 2, pp. 177-188, 2016.

[2] E. Kurniawan and A. Sani, "Analisis Kualitas Real Time Video Streaming Terhadap Bandwidth Jaringan Yang Tersedia,” Singuda ENSIKOM, vol. 9, no. 2, pp. 92-96, 2014.

[3] V. A. B. Harto, R. Primananda, and A. Suharsono, "Analisis Performansi H.264 dan H.265 pada Video Streaming dari Segi Quality Of Service," Pengemb. Teknol. Inf. dan Ilmu Komput., vol. 1, no. 10, pp. 1-2, 2017, doi: 10.3748/wjg.v21.i44.12686.

[4] P. Hakimah, Suroso, and E. Hesti, "Vol. 21 No.1 Februari 2019 Jurnal Momentum,” vol. 21, no. 1, pp. 26-33, 2019, doi: 10.21063/JM.2019.V21.1.26-33.

[5] E. Rohadi et al., "Implementasi Video Streaming Lalu Lintas Kendaraan Dengan Implement Video Streaming Traffic Using Raspberry Pi With,” vol. 5, no. 5, pp. 629-634, 2018, doi: 10.25126/jtiik201851138.

[6] F. Zuli and O. Prasetya, "Implementasi Sistem Plex Media Server Berbasis Wireless Local Area Network,” Pp. 39-49, 2017.

[7] R. Wulandari, “Analisis Qos ( Quality Of Service ) Pada Jaringan Internet ( Studi Kasus : Upt Loka Uji Teknik Penambangan Jampang Kulon - Lipi )," J. Tek. Inform. dan Sist. Inf., vol. 2, pp. 162-172, 2016, doi: 10.28932/jutisi.v2i2.454.

[8] M. Farizi and A. Sani, “Analisis Perbandingan Kinerja Codec H.264 Dan Codec Dirac Untuk Kompresi Live Streaming Pada Perangkat Nsn Flexi Packet Radio(Aplikasi Pada Laboratorium Sistem Komunikasi Radio FT-USU),” Singuda Ensikom, no. 1, pp. 5-18, 2014.

[9] A. 2017 Arsam, "Jurnal Ilmiah Komputer dan Informatika (Komputa) Pembangunan Aplikasi Video Streaming Berbasis Android di STV Bandung." 